\title{
BENEFITS FROM LAGUNA LAKE Perspective of Small Fisher Households
}

\author{
ROSALINA PALANCA-TAN \\ Department of Economics \\ School of Social Sciences \\ Ateneo de Manila University, Quezon City, Philippines \\ rtan@ateneo.edu
}

\begin{abstract}
Fishing is considered to be the most important among the many uses of Laguna Lake, the largest lake in the Philippines and second largest in Southeast Asia. Using primary data gathered through focus group discussions, key informant interviews, and a household survey together with secondary data on revenue and cost estimates for aquaculture and catch fisheries, this paper discusses the lake's role in the economic life of two fishing communities located along the shoreline. The study, which uses a microscopic lens to look at issues from the perspective of small fisher households instead of from that of policymakers and non-government organizations, finds that households in these lakeshore communities are engaged primarily in open fishing, which has been threatened of late by poor water quality and the consequent proliferation of water hyacinths. Only the few well-off residents of these lakeshore communities are able to construct and operate small-scale fish cages while corporations and non-resident individuals own and operate large-scale fish pens. Moreover, while open fishing contributes more to fish production value and employment than does aquaculture, the latter generates more resource rent which accrues to the very few aquaculture capitalists from outside these communities. Some suggestions for redistributing the huge fishing resource rents to poor fishing households in these lakeshore communities are thus presented in this study. The need to address the issue of lake water quality and competing uses, with a view to sustainability and poverty alleviation, is also discussed.
\end{abstract}

\section{KEYWORDS}

aquaculture/fish farming; open fishing/capture fisheries; poverty; resource rent; water pollution 


\section{INTRODUCTION}

Laguna Lake, the largest lake in the Philippines and the second largest in Southeast Asia, has a total surface area of 90,000 ha, accounting for nearly half of the total lake area (190,000 ha) of the country. The benefits derived from it are manifold: it generates fishing income through aquaculture and capture fisheries; supplies water for domestic, industrial, and agricultural uses; supports hydropower production; serves as a retention basin for rainfall and mitigates flood risks in the southern part of Metro Manila; and serves as a sink for residential, commercial, industrial, and agricultural wastewater as well as surface water run-offs and water inflows from the Pasig River. Lastly, it has recreational value that has yet to be fully tapped.

Among the lake's many uses, fishing is considered to be the most important (Laguna de Bay Technical Working Group, 2016). In 1983, the Laguna Lake Development Authority (LLDA), a quasi-government agency with regulatory and proprietary functions for promoting the development and balanced growth of the Laguna Lake area, implemented a Zoning and Management Plan to delineate areas for open fishing, fish cages, fish pens, and a fish sanctuary. A 5,000 ha area is designated as a fish sanctuary while a total of $15,000,10,000$, and 5,000 ha are allocated for aquaculture, fish pens, and fish cages, respectively. The maximum area for fish pen operations is set at 50 ha for a corporation, ten hectares for a cooperative, and five hectares for an individual owner. The maximum area allowed for a fish cage is one hectare. LLDA collects annual resource fees of $\mathrm{P} 6,000$ per hectare from fish pen owners and $\mathrm{P} 4,200$ per hectare from fish cage owners, the proceeds of which are shared by LLDA with local government units for use in environment-related projects.

LLDA's list of fish pen owners in 2018 (LLDA, 2018) included 38 individuals operating 62 fish pens (totaling $818 \mathrm{ha}$ ) and 99 corporations operating 162 fish pens (totaling 6,010 ha). Yet while the lake is populated by large-scale fish pens owned and operated by corporations and individuals who are not residents of the lake-adjacent barangays (villages), poor households in rural and semi-urban barangays of Laguna and Rizal, and even in the urbanized cities of Metro Manila, surround and depend on the lake for their primary source of livelihood, either as fisherfolk in open fishing areas or as operators of small-scale fish cages and ponds. A recent study (Laguna de Bay Technical Working Group, 2016) highlighted the importance of the open fishing done by small fisherfolk in Laguna Lake and found that open fishing surpasses fish 
cages and pens in fish output, revenues, employment, and labor income generation. LLDA estimated open fishing harvest in 2014 to be approximately 107 million $\mathrm{kg}$, or about 33\% more than production from fish cages in the same year. The estimated gross revenue of P3.8 million generated from open fishing in 2014 was double that of fish cages and almost six times that of fish pens. Open fishing in Laguna Lake also provided employment and livelihood to the households of 13,139 fisherfolk and generated labor income of $\mathrm{P} 1.1$ million, more than thrice that of fish cages and more than eight times that of fish pens.

A number of issues regarding the conditions and activities in and around the lake pose threats to the fishing livelihood of households in lakeshore communities. Laguna Lake water is highly euthrophic due largely to inflows of municipal wastewater from households and the services sector (Palanca-Tan, 2015, 2017). Wastewater from livestock and poultry production (Alcantara et al., 2008) and fertilizer residue from croplands (Baldia, Conaco, Nishijima, Imanishi, \& Harada, 2003; Tirado, Bedoya, \& Novotny, 2008) also contribute to this eutrophication, which causes the fast growth and accummulation of water hyacinths that obstruct open fishing and fish cage operations. Indeed, there have been times in recent years when fisherfolk were unable to fish for days and even weeks due to thick beds of water hyacinths that blocked their way to the fishing areas.

The absence of saltwater is also suspected to be a major cause of the proliferation of water hyacinths, with fisherfolk observing that the reverse water flow from Manila Bay to the lake during the dry season appears to be blocked at the Napindan Channel. Apart from the water hyacinths, the absence of saltwater has also introduced predator fish species that reduce fish populations and lower fish catches. Fish cage operators, moreover, claim that fish farming periods are taking much longer (12-18 months instead of the previous 6-8), attributing the slow growth of fish to poor water quality caused by toxic and hazardous industrial pollutants (Tamayo-Zafaralla, Santos, Orozco, \& Elegado, 2002) as well as sediments and silts coming from agriculture, quarrying, deforestation, landfill, land conversion, illegal reclamation, and infrastructure development projects (e.g., the Laguna Lake Highway Project) in the surrounding areas. All these can aggravate the economic vulnerability and deprivation of poor fisherfolk in lakeshore communities who are dependent on small-scale open water fishing and fish farming (cages and ponds). 
This paper, which looks at the role of Laguna Lake in the economic life of lowincome fishing communities that surround it, uses a microscopic lens to explore the issues from the perspective of small fisherfolk instead of from that of policymakers and non-government organizations. Over the years, studies on Laguna Lake have focused mostly on water quality assessments (Barril \& Tumlos, 2002; Chavez, Casao, Villanueva, Paras, Guinto, \& Mosqueda, 2006; Maruyama \& Kato, 2017; Nakajima, Nagaoka, \& Ohgaki, 1996; Rosales \& Rollon, 2011; Varca, 2012; Vicente-Beckett, Pascual, Kwan, \& Beckett, 1991); only a few (Gong, Sakurai, \& Kada, 2015; Israel, 2008) have looked at the impacts the lake has had on the livelihoods of surrounding communities as well as at the need to address such. This study aims to contribute to addressing this gap in the literature.

\section{METHODOLOGY}

\section{The Study Sites}

The vast surface area of Laguna Lake falls within the territories of the highly urbanized National Capital Region (Metro Manila) and the two partly-rural, partlyurban provinces of Rizal and Laguna in Region IVA, which is located south and southwest of Metro Manila. There are a total of 169 barangays bordering the lake-18 from the cities of Taguig and Muntinlupa in Metro Manila, 71 from 9 municipalities in Rizal, and 80 from 18 cities/municipalities in Laguna. This study focuses on two barangays in particular: Barangay Sampad in Cardona Municipality in the Province of Rizal and Barangay Sampiruhan in Calamba City in the Province of Laguna.

Despite having become increasingly more urbanized, the two provinces of Rizal and Laguna still make substantial contributions to the country's fisheries output due to their proximity to Laguna Lake. Rizal and Laguna ranked $8^{\text {th }}$ and $10^{\text {th }}$, respectively, among all 81 provinces in the country in terms of contribution to the Philippines's municipal fishing catch. From 2008-2017, municipal fishing catch in Laguna totaled 382 thousand metric tons, accounting for 3\% of the country's total municipal fishing catch, while Rizal's municipal fishing catch of 456 thousand metric tons was roughly $4 \%$ of the country's total output. In terms of contribution to Philippine aquaculture production, Rizal and Laguna ranked lower $-13^{\text {th }}$ and $32^{\text {nd }}$, respectively. In Laguna, aquaculture produce was only 106 thousand metric tons or $0.4 \%$ of total Philippine aquaculture produce during the period 2008-2017. Rizal's output of 483 thousand 
metric tons, on the other hand, comprised $2 \%$ of the country's aquaculture produce (PSA, 2019).

The contributions of Laguna and Rizal to Philippine municipal fishing become less significant, however, when measured in value terms. This is because the types of fish caught in Laguna Lake are the cheaper varieties (Israel, 2008; Saguin, 2014). Tilapia, the main fish variety caught in open fishing areas in Laguna Lake, is currently the cheapest type of fish in the country, with fish varieties caught in marine waters being more preferred and more expensive. Hence, even if Laguna and Rizal ranked high in municipal fishing volume, they ranked very low- $41^{\text {st }}$ and $53^{\text {rd }}$, respectivelyin terms of fishing value. The contributions of Rizal and Laguna to Philippine aquaculture, on the other hand, are slightly higher in value terms $\left(12^{\text {th }}\right.$ and $30^{\text {th }}$, respectively) than in volume terms as the price per metric ton of seaweed is much lower than those of tilapia and milkfish, the two main aquaculture products of Laguna Lake. Seaweeds, tilapia, and milkfish are the top aquaculture products of the Philippines.

Figure 1 shows the locations of Barangays Sampiruhan and Sampad. Calamba City in Laguna, which houses more than ten industrial parks, claims to be the premier industrial hub outside of Metro Manila. Major income sources in the city are from manufacturing, tourism, agriculture, and services; only $2 \%$ or 4,157 of the city's 206,231 gainful workers are skilled agricultural forestry and fishery workers (PSA, 2016). The city is bounded by Laguna Lake in the east, with 11 of its 54 barangays adjacent to the west bay of the lake. Sampiruhan, one of these 11 that share the coastline, has remained a rural village with fishing as its main economic activity-of its 81 ha land area, 60\% is residential, 30\% is for agriculture (vegetable farms and fish ponds), and only $10 \%$ is commercial. In 2016, Sampiruhan had a population of 9,927 people living in 2,922 households (City Government of Calamba Official Website, 2018).

Sampad, a tiny lakeshore barangay in Cardona, has a population of only 2,125 in 380 households (DSWD, 2015). Cardona, a $3^{\text {rd }}$ class municipality in Rizal, is a vertical strip of land bordering the west side of the central bay of Laguna Lake. As a consequence, 15 of its 18 barangays are along the shoreline of the lake, where fishing is the primary means of livelihood. Of the municipality's 20,006 gainful workers, $16.3 \%$ or 3,262 are skilled in agricultural forestry and fishery (PSA, 2016). 
Cardona has been known for its fishing industry since the early 1970s, when a fish propagation program was pioneered in the lakeshore areas of Cardona and the Philippine Fisheries Development Authority developed the Cardona Municipal Fish Port. The municipality is visited by fish distributors from different regions, and its main source of revenue is income from the municipal fish port.

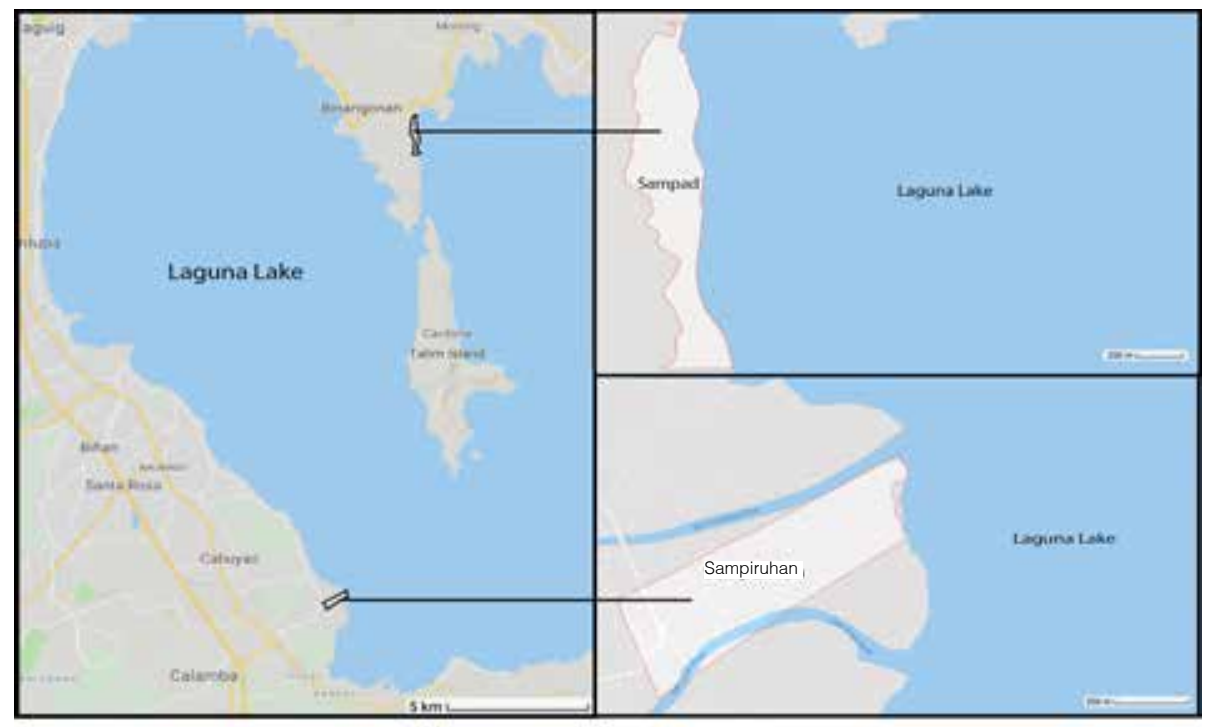

Figure 1: Survey Areas-Barangay Sampiruhan in Calamba, Laguna and Barangay Sampad in Cardona, Rizal

\section{Data Collection}

The study employed primary data collection methods, namely key informant interviews (KIIs), focus group discussions (FGDs), and a comprehensive household survey. FGDs with representative households in combination with KIIs with community leaders, local government officials, and non-government organizations were undertaken to obtain background information and provide inputs for the drafting of the survey instrument.

The 24-page comprehensive household survey instrument consisted of five parts. Part I covered household composition and asked basic demographic questions about each household member. Part II, which made up half of the questionnaire (12 out of 24 pages), contained detailed questions about the fishing activities of the household. Part III dealt with the household's consumption and asset profile-consumption 
composition and pattern, ownership of physical assets (durable household goods such as furniture and appliances and other items that may be used for livelihood activities such as a refrigerator, computer, and automobile), financial assets and liabilities (savings and borrowing behavior), and access to utilities (electricity and water) and sanitation facilities. Part IV consisted of social capital questions, i.e., about membership in formal and informal organizations/social networks as well as questions on trust/cooperativeness to measure behavioral social capital. Part V posed questions about the experience of the household with strong typhoons and flooding and its adaptation measures to such.

This paper focuses on the results of the fishing part of the questionnaire; the results of the other parts were used by an earlier study (Palanca-Tan, 2020) which focused on the households' consumption behavior and vulnerabilities. In Part II of the questionnaire, household fishing activities were categorized into open-fishing (municipal fishing) and aquaculture. Questions about open fishing focused on the most commonly used methods, equipment and materials used and their costs, and fish most frequently caught. Questions about aquaculture dealt with types of fish farms, the costs of construction, equipment, fingerlings and feeds, growing period, and types and volumes of fish harvests. Problems facing the fisherfolk, their future plans, and the perceived impact of government projects in the Laguna Lake area were also considered.

A total sample of 113 fishing households from Sampiruhan and 65 from Sampad was generated for the study. In Barangay Sampad, respondents were selected using a systematic sampling procedure-from a random starting point, houses were visited according to a fixed interval of five. Every house that was approached needed to be the $5^{\text {th }}$ house from the last household that agreed to participate in the study; if a household refused, the next house would be approached. In Barangay Sampiruhan, respondents were selected randomly by stationing student enumerators along the shore to interview fisherfolk as they arrived from the lake. The surveys were implemented through personal interviews during the months of March-September 2018. College students majoring in Economics served as survey enumerators as part of a service-learning activity for their Statistics class. ${ }^{1}$

${ }^{1}$ These two barangays were selected as study sites primarily because of this student service-learning aspect of the research project and based on fishing activities as well as safety considerations. They are among candidate survey barangays in Laguna and Rizal identified by 


\section{FINDINGS AND DISCUSSION}

\section{Survey Results: Fishing Livelihood of Households around Laguna Lake}

This section presents the results of the survey on fishing activities of households in Sampiruhan and Sampad. Most of the fishing households in the sample are engaged in open (municipal) fishing-of the 113 respondents in Sampiruhan, three-fourths (83 households) are involved in open fishing while only a fifth (24 households) are fish farm operators; in the case of Sampad, 54 out of 65 fishing households (83\%) engage in open fishing and about the same proportion as in Sampiruhan $(21.5 \%)$ undertake fish farm operations. While some respondents are engaged in both open fishing and fish farm operations, it is understandable why most of the households are into open fishing as this provides a daily source of income and requires lower financial capital. Fish farming, on the other hand, requires the construction of fish cages, the cost of which varies according to size and materials. The cheapest and smallest farms require at least $\mathrm{P} 40,000$ in capital, and harvesting from these facilities requires waiting for a couple of months. This is because the fish farm cycle is relatively longer in the case of Laguna Lake, where natural food instead of feeds is used.

There are very few resident fish farm workers in either barangay (ten or $8 \%$ of respondents in Sampiruhan and ten or 15\% of respondents in Sampad). Fish farms operated by households residing within the barangays are small-scale, and can be run and cared for by the household head with some help from other household members without having to employ regular workers from outside (except during harvest time). Only large-scale farm operations owned by corporations employ managers and workers, most of whom are not residents of the neighboring barangays. These farm workers are usually recruited from low-income rural provinces in other parts of the Philippines and are stay-in employees living in small shanty huts located in the vicinity of the fish farms. This explains the small proportion of fish farm workers among the residents of the barangays.

Fishponds, which usually grow catfish, predominate in Sampiruhan, where the level land (formerly planted with vegetables and rice) near the lakeshore and availability of groundwater make pond operation viable. Much of the agricultural 
land in many parts of Luzon (particularly in Central Luzon, which is known to be the rice granary of the Philippines) has been converted into fishponds due to higher returns; indeed, a study conducted by ADB (2005) found that tilapia farming was four times more profitable than rice farming. It is not surprising, therefore, that vegetable and rice farms in Sampiruhan have been converted recently into fishponds in pursuit of higher profits. Fish farms in Sampad, on the other hand, are mostly cages and pens in the lake given the hilly and rolling land along the shoreline.

The two sub-sections that follow summarize the findings for open fishing and aquaculture.

Open Fishing. In Sampiruhan, the use of gill nets and fish corrals (a kind of fish trap structure) are the primary means of catching fish. In Sampad, the use of gill nets (78\%) dominates the use of fish corrals (11\%). Secondary methods of catching fish in the two barangays are diving and the use of fishing rods and fish dome traps. The choice of fishing methods employed appears to be dependent more on traditional practices as learned from older members of the community rather than on training and the costs of gear and materials.

Boats, boat motors, and fish nets are the basic gears used in open fishing. The average costs of boats and motors used by fisherfolk in Sampiruhan and Sampad are similar, indicating a similar scale of fishing in the two communities. The costs of fish nets and frames used in Sampiruhan are about double the costs for the same in Sampad; this is likely due to the more widespread use of fish corrals (which are made of nets and frames) in Sampiruhan. As for gasoline, which is used to run the boat motors, fisherfolk consume, on average, P105 (in Sampad) to P139 (in Sampiruhan) worth per fishing trip. The standard deviations for both barangays are quite high, however, which may be indicative of highly variable fishing hours.

A majority of fisherfolk in both barangays used their own household savings to purchase fishing gears (65\% for Sampiruhan and 56\% for Sampad). The same proportion of respondents (13\%) in the two barangays also received financial assistance from relatives and/or friends. During the KIIs, some community leaders indicated that they provide and lend their boats, nets, and other gears to fisherfolk relatives and friends who need such; indeed, there are several cases where an informal "business" agreement was reached wherein they provide the gear and materials to the fisherfolk in exchange for a share in the harvest. 
Borrowing does not appear to be a widespread option for funding gear and equipment purchases in Sampiruhan. Only 11\% of respondents borrowed funds from relatives or friends to purchase gear, and more formal funding sources, e.g., cooperatives, banks, and government institutions, are rarely availed of-only two households availed of credit from government institutions and only three did so from cooperatives and banks. In Sampad, however, nearly half (42\%) of the respondents borrow from cooperatives for the purchase of open fishing gear. Higher proportions of fisher households from Sampad likewise borrow funds from government institutions, friends, relatives, and banks. It appears, therefore, that more financial assistance from cooperatives and government is available in Sampad than in Sampiruhan. This may be because Sampiruhan, despite being a low-income rural barangay, belongs to a first-class city and is therefore no longer a priority area for assistance from NGOs, cooperatives, and government agencies.

In terms of daily expenses for open fishing materials, close to $80 \%$ of fisher households in both barangays use their own savings. Only 2 out of 83 respondent households (3\%) from Sampiruhan borrow funds for daily fishing material requirements while a substantial proportion (73\%) of Sampad households borrow from relatives, friends, and cooperatives in addition to using their savings. This can be indicative of more prevalent subsistence living conditions in Sampad relative to Sampiruhan. Those who borrow for daily fishing materials in both barangays indicate borrowing once every week, on average.

In Sampiruhan, the fish varieties most frequently and abundantly caught through open fishing are tilapia (60\% of respondents), big head carp (19\%), catfish (12\%), and silver perch (6\%). In Sampad, tilapia is the most frequently and abundantly caught fish among almost all of the open fishers surveyed (93\%), followed by milkfish (4\%) and catfish (2\%). Milkfish, on the other hand, emerged as one of the most frequently farmed fish in Sampad as fish pens growing milkfish abound in the Rizal area. Milkfish is not indicated by any respondent in Sampiruhan, which is relatively far from the milkfish pen area.

With more varieties of higher value fish (catfish and silver perch) caught in Sampiruhan, the average selling price of fish in this barangay is slightly higher than in Sampad, where the catch is mainly tilapia. Table 1 reveals that the average daily fish catch ranges between 3-106kg in Sampiruhan and 3-59kg in Sampad. 
The standard deviations are much higher than the mean values, implying wide differences in the scales of operation among fisherfolk-on a bad day, the catch can be as low as $3 \mathrm{~kg}$, most of which is sold and only $0.5-0.8 \mathrm{~kg}$ is allocated for household consumption, giving the fisherfolk a daily sales income of just about P96-P103, roughly a third of the minimum wage rate of the area. A good day's catch, however, gives the fisherfolk an average daily sales amount of $\mathrm{P} 1,770$ and $\mathrm{P3}, 456$ in Sampad and Sampiruhan, respectively, and leaves them with more than $4 \mathrm{~kg}$ of fish for consumption at home or for giving away to relatives and friends.

\begin{tabular}{|c|c|c|c|c|c|c|}
\hline & \multicolumn{2}{|c|}{ Bad Day } & \multicolumn{2}{|c|}{ Good Day } & \multicolumn{2}{|c|}{ Last Remembered Catch } \\
\hline & Mean & Std Dev & Mean & Std Dev & Mean & Std Dev \\
\hline & \multicolumn{6}{|c|}{ SAMPIRUHAN } \\
\hline Catch $(\mathrm{kg})$ & 2.6 & 4.3 & 105.9 & 206.3 & 14.9 & 34.4 \\
\hline Amount sold (kg) & 2.1 & 3.9 & 101.5 & 206.2 & 13.9 & 34.8 \\
\hline Sales value $(\mathbb{P})$ & 96 & 131 & 3,456 & 5,757 & 575 & 11,778 \\
\hline \multirow[t]{2}{*}{$\begin{array}{c}\text { Average price } \\
\text { per kg }(尹)\end{array}$} & 36 & 37 & 48 & 39 & 46 & 41 \\
\hline & \multicolumn{6}{|c|}{ SAMPAD } \\
\hline Catch (kg) & 3.0 & 2.6 & 59.0 & 97.1 & 6.5 & 6.8 \\
\hline $\begin{array}{l}\text { Amount sold } \\
(\mathrm{kg})\end{array}$ & 2.2 & 2.2 & 54.8 & 95.2 & 6.5 & 9.8 \\
\hline Sales value $(\mathbb{P})$ & 103 & 88 & 1,770 & 2,936 & 300 & 494 \\
\hline $\begin{array}{l}\text { Average price } \\
\text { per kg } \\
(\mathrm{P})\end{array}$ & 37 & 21 & 41 & 16 & 39 & 25 \\
\hline
\end{tabular}

Table 1: Daily Fish Catch

About 70\% of the catch in both Sampad and Sampiruhan is sold at the nearest wet market, further reflecting the preponderance of small-scale fishing in both barangays.

Fishing-related problems cited by the majority of respondents in Sampiruhan include typhoons $(77 \%)$, the proliferation of water hyacinths $(62 \%)$, water pollution $(61 \%)$, and lowered fish stocks (58\%). Substantial proportions of fisherfolk in Sampiruhan also cited shortages of financial capital (45\%), flooding (38\%), and low and fluctuating fish prices (32\%). A few cited illegal fishing and lake robbery (piracy of fishing gear and catch). To address the problem of shortages in financial capital, 
subsistence fisherfolk enter into a fish catch-sharing arrangement with those who have financial capital and/or fishing equipment/material.

Problems cited by the majority of respondents in Sampad include the proliferation of water lilies (98\%), typhoons (74\%), the shortage of funds (59\%), lowered fish stocks (59\%), water pollution (56\%), and the limited/slow growth of fish (50\%). The Metro Manila and Rizal portions of the lake are more prone to the fast growth of water lilies due to large inflows of untreated municipal wastewater and the increasing absence of saltwater. Sampad fisherfolk observed that the reverse water flow from Manila Bay to the lake during the dry season seems to have stopped in recent years, and said that they were unable to fish for a couple of weeks during the third quarter of 2018 as thick beds of water hyacinths blocked their way to the fishing areas.

The last question asked of the respondents who were engaged in open fishing was about whether or not they plan to continue this livelihood activity. An overwhelming majority in both Sampiruhan (64\%) and Sampad (83\%) answered in the affirmative. In Sampad, the primary reason given was the lack of other job opportunities as the barangay is somewhat secluded and far from the commercial area of Rizal. In Sampiruhan, on the other hand, which is part of the fast-developing city of Calamba, a significant number of respondents specified other reasons (38\%), due mainly to a personal preference for fishing: "it is what I want to do for as long as my body can still do it," "it is a form of recreation for me," "it is what I am used to," "it is what my mental capacity can handle," "I prefer fishing because I have no boss here." A comparable proportion of respondents (40\%) in Sampiruhan also indicated the absence of other job opportunities. About a quarter of respondents in both barangays considered open fishing to be a good source of income. Only two of the fisherfolk interviewed in Sampad intend to discontinue fishing in the next five years to pursue other work and because of low fishing income and the problem of the water lilies. Among those planning to quit open fishing in Sampiruhan (27\% of open fishing respondents), their reasons for doing so include low fishing income, pursuit of other types of work, that "fishing is hard," old age, and water pollution.

Aquaculture. There is a difference in the kind of fish farming undertaken between Sampiruhan and Sampad. In Sampiruhan, fish farm operations involve growing mainly catfish in fishponds near the lakeshore-a significant $82 \%$ of the farm 
operator respondents grow catfish, with only $42 \%$ growing tilapia and much fewer (4\%) growing milkfish. In Sampad, on the other hand, fish farms are all in the form of fish cages in the lake and grow tilapia (86\%), milkfish (43\%), and other fish species $(64 \%)$.

The predominant reason for engaging in fish farming is its high earning potential (cited by more than $85 \%$ of respondents in both barangays). In Sampiruhan, household savings are, as is the case with open fishing, the primary source of funds for fish farm construction (as reported by $76 \%$ of fish farm owners). In Sampad, while only $43 \%$ of fish farm owners use their own savings, a substantial proportion (21\%) borrowed funds from cooperatives, similar to open fishing. A similar proportion (slightly over 10\%) of fish farm owners in both Sampiruhan and Sampad received financial assistance from relatives. For the daily operations of the fish farms, all of the fish farm owners/operators in Sampiruhan use household savings except for two respondents, one of whom has a financier from another municipality while the other borrows money from a bank. In Sampad, sources of funds for daily operations are more diverse; these include household savings (43\%), assistance from relatives/friends (14\%), and borrowing from cooperatives $(21 \%)$, banks $(7 \%)$, and relatives $(7 \%)$.

Table 2 reveals the scale and financial conditions of the small-scale fish farm operations of residents in the vicinity of Laguna Lake. The fish farm owners included in the survey sample have been engaged in aquaculture for an average of 15-16 years. In Sampiruhan, a fish farm owner has 5 farms on average, each measuring $584 \mathrm{~m}^{2}$ for a total fish farm area of 1,300 $\mathrm{m}^{2}$. In Sampad, the average fish farm owner has only one fish cage, which is usually $2,800 \mathrm{~m}^{2}$ in size. The contrast in the nature and scale of fish farm operations between Sampiruhan and Sampad can thus be noted-aquaculture in Sampiruhan involves mainly fishpond structures for growing catfish along the shoreline while in Sampad it is composed mainly of fish cages for tilapia and other fish species that grow in the vast lake area. The average farm size in Sampiruhan is much lower therefore than in Sampad, and the average cost of fish farm construction in Sampiruhan is about double that in Sampad as a pond system setup involves a water supply source (deep well) with a pump system for regularly changing pond water (compared to fish cages that require only bamboo frames and nets). The much higher costs of fingerlings and commercial feeds used in Sampiruhan are also indicative of the more intensive aquaculture methods employed there. 
Aquaculture in the waters of Laguna Lake in general, as is the case with Sampad, is dependent only on natural food.

The average harvest volume from Sampiruhan fish ponds is $1,731 \mathrm{~kg}$ while that of Sampad fish cages is $2,259 \mathrm{~kg}$. In terms of monetary value, however, Sampiruhan's average total sales revenue of $\mathbb{P} 100,367$ is more than twice Sampad's $\mathbb{P} 42,613$. This is because Sampiruhan's predominantly catfish and big tilapia variety harvests command a higher price (尹58.02 per kg on average) compared to Sampad's small tilapia, big head carp, and other low price fish varieties.

\begin{tabular}{|c|c|c|c|c|}
\hline & \multicolumn{2}{|c|}{ Sampiruhan $(n=24)$} & \multicolumn{2}{|c|}{ Sampad $(n=14)$} \\
\hline & Mean & Std Dev & Mean & Std Dev \\
\hline $\begin{array}{c}\text { Number of years } \\
\text { engaged in aquaculture }\end{array}$ & 15 & 13 & 16 & 10 \\
\hline Number of fish cages/pens/ponds & 5 & 4 & 1.1 & 0.3 \\
\hline Size of each fish cage/pen/pond $\left(\mathrm{m}^{2}\right)$ & 584 & 1,969 & 2,773 & 3,985 \\
\hline $\begin{array}{l}\text { Total area of all fish cages/pens/ponds } \\
\qquad\left(\mathrm{m}^{2}\right)\end{array}$ & 1,279 & 2,211 & 2,831 & 3,783 \\
\hline $\begin{array}{l}\text { Cost of fish cage/pen/pond } \\
\text { construction }(\mathrm{P})\end{array}$ & 41,188 & 46,622 & 22,500 & 24,324 \\
\hline \multicolumn{5}{|c|}{ INPUTS } \\
\hline Number of fingerlings used & 9,098 & 10,302 & $9,515.4$ & $6,624.2$ \\
\hline Total cost of fingerlings ( $(\mathbf{P})$ & 43,404 & 51,446 & 23,667 & 35,247 \\
\hline Number of sacks of feeds used & 51 & 187 & 2.9 & 1.7 \\
\hline Total cost of feeds $(\stackrel{P}{ })$ & 3,190 & 8,813 & 522 & 3,003 \\
\hline Growing period (no. of months) & 15 & 11 & 8.8 & 2.8 \\
\hline \multicolumn{5}{|c|}{ HARVEST AND SALES } \\
\hline Amount of harvest (kg) & $1,731.4$ & $2,917.0$ & $2,258.9$ & $3,484.2$ \\
\hline Sold (kg) & $1,730.0$ & $2,917.6$ & $2,237.8$ & $3,495.6$ \\
\hline Value of sales $(\stackrel{P}{ })$ & 100,367 & 210,968 & 42,613 & 83,630 \\
\hline Price per kg (P) & 58.02 & & 19.04 & \\
\hline
\end{tabular}

Table 2: Fish Farm Operations

The problems cited by most fish farmers (88\%) in Sampiruhan are typhoons and flooding, with a little less than half citing water pollution (44\%) and insufficient financial capital (40\%). Other problems cited are the proliferation of water lilies (24\%), bird and fish predators and/or parasite infestation (20\%), fish kill (20\%), high 
feed prices/lack of supply (16\%), low/volatile fish prices (16\%), high fry mortality (16\%), high fingerling prices/lack of supply (8\%), lack of training/knowledge in aquaculture (8\%), the construction of highways/dikes that makes it difficult to go to the fish cages/pens/ponds (8\%), and government's dismantling of/ban on fish cages/ pens/ponds (8\%). Stringent aquaculture policies (e.g., zoning, license registration procedures/fees) are not cited at all—the fish ponds in Sampiruhan are apparently not subject to strict government control as much as the fish cages and pens in lake waters are. Typhoons and flooding are likewise the most cited problems by fish farmers in Sampad (71\%), although a majority also cite water pollution and the proliferation of water lilies (57\%). All the other problems listed in the questionnaire as mentioned above were cited to a lesser extent except for fry mortality and insufficient knowledge in aquaculture. Despite such problems, however, the overwhelming majority of fish farm owners in Sampiruhan (two-thirds or 16 out of 24) and Sampad (86\% or 12 out of 14) have plans of continuing their farming operations.

Two main themes emerge from the survey results. First is the preponderance of households in the lakeshore communities that undertake small-scale fishing, with most households around Laguna Lake engaged mostly in open fishing rather than fish farming. Open fishing activities utilize very basic, low-cost fishing gear and materials (with large variations in daily fishing costs merely being indicative of highly variable fishing hours) which are funded mainly by a household's own savings and/or through borrowing from relatives and friends. Likewise, the aquaculture done by a few households in the lakeshore communities is small-scale fish cage farming, with an average of one cage measuring about two ha per household.

The second theme is that fishing activities-and hence the livelihood of the fishing households-are seriously affected by pollution and other environmental conditions in the lake ecosystem. The greatest proportions of respondents in both barangays cited the proliferation of water hyacinths, water pollution, and typhoons as the biggest problems and obstacles in their fishing activities.

The remainder of this section discusses and assesses these two issues within the larger fishing, social policy, and sustainable development context of the Laguna Lake ecosystem. 


\section{Resource Rents from Fishing in Laguna Lake: Where are These Going?}

A look at all forms of fishing activities at the lake and at the key players in these activities can shed light on the relative share of fishing households residing around Laguna Lake in the total fishing income or resource rent generated from the lake. Analyzing data on the costs, revenues, and resource rents of open fishing, fish cages, and pens in a recent LLDA study (Laguna de Bay Technical Working Group, 2016) and combining such with LLDA records of fisherfolk and fish cage and pen owners, this section reveals that only minimal resource rents accrue to each fisherfolk and fish cage owner-尹 $\mathbf{P} 142,933$ and $尹 90,500$, respectively_every year, most of whom are residents of the lakeshore communities, compared to the exorbitant resource rents enjoyed every year by a few non-lakeshore resident, fish pen-owning corporations and individuals at $\mathrm{P} 2,145,700$ each.

The first panel of Table 3 presents LLDA's estimates of the fish output, revenues, and costs of open fishing, fish cages, and pens (Laguna de Bay Technical Working Group, 2016). Cost to revenue ratios were calculated (second panel of the same table) using these estimates, and the results reveal that open fishing has much lower intermediate input, fixed capital input, and user cost of capital to revenue ratiosand hence a much higher resource rent (net gain) to revenue ratio-compared to fish cages. Open fishing generates more revenues from every peso of fish caught than fish farming in cages generates for every peso of fish harvested. Cost ratios for the fish pens are much lower, however, likely due to economies of scale, which results in a very high resource rent to revenue ratio. These estimates highlight tremendous gains from the use of Laguna Lake, a natural water ecosystem that can generate natural food even for large-scale aquaculture operations.

On a per hectare basis, the resource rent estimates for open fishing, fish cages, and fish pens are $\mathrm{P} 24,000$, $\mathrm{P} 95,000$, and $\mathrm{P} 49,000$, respectively. There is a higher resource rent per hectare from fish cages than from fish pens due to the latter's larger farm area. Thus, with LLDA's annual "resource" fees of only $\mathrm{P} 6,000$ per ha for fish pens and $\ngtr 4,200$ per ha for fish cages, which are merely minute fractions of their respective resource rents (12\% for fish pens and $4 \%$ for fish cages), so much of the resource rent generated from Laguna Lake is enjoyed by the very few fish pen owners operating there, as is elaborated below. 


\begin{tabular}{|c|c|c|c|c|}
\hline & OPEN FISHING & FISH CAGE & FISH PEN & TOTAL \\
\hline \multicolumn{5}{|c|}{ LLDA Estimates } \\
\hline Area (hectares) & 78,627 & 3,356 & 10,415 & 92,397 \\
\hline $\begin{array}{c}\text { Catch/harvest } \\
\text { (in thousands of kg) }\end{array}$ & 106,669 & 80,395 & & \\
\hline $\begin{array}{c}\text { Gross revenues } \\
(\mathrm{P} \text { million })\end{array}$ & 3,846 & 1,910 & 691 & 6,447 \\
\hline $\begin{array}{l}\text { Labor costs } \\
(\mathrm{P} \text { million })\end{array}$ & 1,077 & 343 & 131 & 1,551 \\
\hline $\begin{array}{l}\text { Intermediate inputs } \\
\quad(\mathrm{P} \text { million })\end{array}$ & 715 & 727 & 31 & 1,473 \\
\hline $\begin{array}{l}\text { Fixed capital inputs } \\
\text { (尹 million) }\end{array}$ & 150 & 340 & 10 & 500 \\
\hline $\begin{array}{l}\text { User cost of } \\
\text { fixed capital } \\
\text { (尹 million) }\end{array}$ & 15 & 179 & 6 & 200 \\
\hline $\begin{array}{l}\text { Resource rent } \\
\text { (尹 million) }\end{array}$ & 1,878 & 320 & 514 & 2,712 \\
\hline \multicolumn{5}{|c|}{ Calculated Cost and Profit Ratios } \\
\hline $\begin{array}{c}\text { Labor cost/revenues } \\
(\%)\end{array}$ & 28.0 & 18.0 & 19.0 & 24.1 \\
\hline $\begin{array}{c}\text { Intermediate/revenues } \\
(\%)\end{array}$ & 18.6 & 38.1 & 4.5 & 22.8 \\
\hline $\begin{array}{c}\text { Fixed capital/revenues } \\
(\%)\end{array}$ & 3.9 & 17.8 & 1.4 & 7.8 \\
\hline $\begin{array}{c}\text { User cost of fixed } \\
\text { capital/revenues (\%) }\end{array}$ & 0.4 & 9.4 & 0.9 & 3.1 \\
\hline $\begin{array}{c}\text { Resource rent/revenues } \\
(\%)\end{array}$ & 48.8 & 16.7 & 74.4 & 42.1 \\
\hline $\begin{array}{c}\text { Resource rent/area } \\
\text { (尹 thousand/ha) }\end{array}$ & 24 & 95 & 49 & 29 \\
\hline
\end{tabular}

Table 3: Cost and Profit Ratios of Fishing in Laguna Lake (Laguna de Bay Technical Working Group, 2016: 52-56 for panel 1; author's computations for panel 2)

Table 4 summarizes the profiles of fish pen owners in Laguna Lake in 2018. Most fish pen owners-99 out of 137 , or $72 \%$-are corporations. While majority (77) of the 99 corporate owners have only one fish pen each, a considerable number (22) own an average of four fish pens each, occupying a total area of 3,039 ha, which is almost half (45\%) of the total registered fish pens' area of 6,831 ha. As for the 38 individual 
fish pen owners (who are not even residents of the lakeshore barangays), 30 have one fish pen each (with an average size of $7.2 \mathrm{ha}$ ) and eight have an average of four pens each (with an average size of $18.8 \mathrm{ha}$ ). These data reveal scales of aquaculture operations that are well beyond the means of small fisherfolk.

\begin{tabular}{|c|c|c|c|c|c|}
\hline & \multicolumn{2}{|c|}{ CORPORATION OWNERS } & \multicolumn{2}{|c|}{ INDIVIDUAL OWNERS } & \multirow[b]{2}{*}{ Total } \\
\hline & $\begin{array}{l}\text { Single fish } \\
\text { pen owners }\end{array}$ & $\begin{array}{l}\text { Multiple fish } \\
\text { pen owners }\end{array}$ & $\begin{array}{l}\text { Single fish } \\
\text { pen owners }\end{array}$ & $\begin{array}{l}\text { Multiple fish } \\
\text { pen owners }\end{array}$ & \\
\hline $\begin{array}{l}\text { No. of fish } \\
\text { pen owners }\end{array}$ & 77 & 22 & 30 & 8 & 137 \\
\hline $\begin{array}{l}\text { No. of fish } \\
\text { pens }\end{array}$ & 77 & 85 & 30 & 32 & 224 \\
\hline $\begin{array}{c}\text { Average } \\
\text { no. of fish } \\
\text { pens per } \\
\text { owner }\end{array}$ & 1.0 & 3.9 & 1.0 & 4.0 & 1.6 \\
\hline $\begin{array}{l}\text { Total fish } \\
\text { pen area } \\
\text { (hectares) }\end{array}$ & $2,974.2$ & $3,039.1$ & 214.9 & 602.7 & $6,830.9$ \\
\hline $\begin{array}{c}\text { Average } \\
\text { size of } \\
\text { fish pens } \\
\text { (hectares) }\end{array}$ & 38.6 & 35.8 & 7.2 & 18.8 & 30.5 \\
\hline $\begin{array}{l}\text { Average } \\
\text { fish pen } \\
\text { area per } \\
\text { owner } \\
\text { (hectares) }\end{array}$ & 38.6 & 138.1 & 7.2 & 75.3 & 49.9 \\
\hline
\end{tabular}

Table 4: Fish Pen Ownership in Laguna Lake

(LLDA, 2018; author's compilation and computations)

After deducting the resource fee of $\mathrm{P} 6,000$ per ha of fish pen collected by LLDA from the resource rent of $\mathrm{P} 49,000$ per ha, about $\mathrm{P} 293,960,900$ worth of resource rent per year is retained by just 137 registered fish pen owners (corporate and individual). Each fish pen owner thus keeps $\mathrm{P} 2,145,700$, on average, of resource rent per year for itself. The largest amount of resource rent is enjoyed by the multi-pen corporate owner $(\mathrm{P} 5,938,300)$ followed by the multi-pen individual owner $(\mathrm{P} 3,237,900)$.

Most fish cages, on the other hand, are owned by fisherfolk residing in the lakeshore barangays. Table 5 reveals that of the 340 fish cage owners surveyed, 213 or $63 \%$ are residents of Rizal, 79 or 23\% are residents of Metro Manila, and 48 or 14\% 
are residents of Laguna. Barangay Sampad, however, has only three fish cage owners even though Cardona accounts for 73 (34\%) of the fish cages in Rizal. In Laguna, most of the fish cage owners (34 or 71\%) are from Biñan. There is no registered fish cage owner in Barangay Sampiruhan-as revealed by survey results, aquaculture operations in Sampiruhan are made up mostly of fishponds on land along the shore of Laguna Lake. Fish cage owners registered with LLDA are the relatively better-off fisherfolk in the lakeshore communities who have the financial resources to construct one hectare of fish cage and pay the annual fee of $\mathrm{P} 4,500$. As fish cage ownership is limited to individuals and the fish cage area for every owner is limited to one ha, the average annual resource rent enjoyed by each fish cage owner is just about $\mathrm{P90,500.}$

\begin{tabular}{|c|c|c|c|c|c|c|c|}
\hline \multirow{2}{*}{ AREA } & \multicolumn{2}{|c|}{$\begin{array}{c}\text { ADDRESS OF } \\
\text { FISH CAGE } \\
\text { OWNER }\end{array}$} & \multicolumn{5}{|c|}{ LOCATION OF FISH CAGE } \\
\cline { 2 - 8 } & $\begin{array}{c}\text { No. of } \\
\text { fish } \\
\text { cages }\end{array}$ & $\begin{array}{c}\text { Share (\%) } \\
\text { in total } \\
\text { fish cages }\end{array}$ & $\begin{array}{c}\text { No. of } \\
\text { fish } \\
\text { cages }\end{array}$ & $\begin{array}{c}\text { Share (\%) } \\
\text { in total } \\
\text { fish cages }\end{array}$ & $\begin{array}{c}\text { Total } \\
\text { area } \\
\text { (ha) }\end{array}$ & $\begin{array}{c}\text { Share } \\
\text { (\%) in } \\
\text { total area }\end{array}$ & $\begin{array}{c}\text { Ave. area } \\
\text { per fish } \\
\text { cage (ha) }\end{array}$ \\
\hline Total & 340 & 100.0 & 340 & 100.0 & 249.9 & 100.0 & 0.73 \\
\hline Rizal & 213 & 62.6 & 223 & 65.6 & 159.8 & 64.0 & 0.72 \\
\hline \multicolumn{1}{|c|}{ Cardona } & 74 & 21.8 & 85 & 25.0 & 58.7 & 23.5 & 0.69 \\
\hline \multicolumn{1}{|c|}{ Sampad } & 4 & 1.2 & 8 & 2.4 & 4.5 & 1.8 & 0.56 \\
\hline Others & 70 & 20.6 & 77 & 22.6 & 54.2 & 21.7 & 0.70 \\
\hline $\begin{array}{l}\text { Metro } \\
\text { Manila }\end{array}$ & 79 & 23.2 & 67 & 19.7 & 64.0 & 25.6 & 0.96 \\
\hline Laguna & 48 & 14.1 & 50 & 14.7 & 26.0 & 10.4 & 0.52 \\
\hline
\end{tabular}

Table 5: Registered Fish Cages

(LLDA, 2018; author's compilation and computations)

Likewise, in sharp contrast with the huge resource rent enjoyed by fish pen owners, total resource rent from open fishing of $\mathrm{P} 1,878$ million is shared among 13,139 fisherfolk, which results in an annual resource rent of only $尹 142,933$ per fisher.

Lake Water Quality Issues Affecting Fishing Households' Livelihood

Survey results indicate that fisherfolk in these two lakeshore barangays consider lake water pollution to be a serious obstacle in their fishing livelihood activities. Fish cages and even large-scale fish pen operations in Laguna Lake rely generally on natural food (and not commercial feeds), and hence they do not contribute substantially to lake water pollution. Instead, it is both aquaculture and open fishing that are 
negatively affected by poor lake water quality, most particularly eutrophication that causes the proliferation of water hyacinths. Municipal wastewater disposed into the lake without adequate treatment is one major cause of eutrophication-indeed, much of the municipal wastewater eventually flows into the lake without adequate treatment due to a lack of wastewater treatment facilities (Palanca-Tan, 2015, 2017).

The absence of saltwater is another major cause of excessive water hyacinth growth. The reverse flow of water from Manila Bay to Laguna Lake during the dry season allows saltwater to enter the lake and combine with freshwater to produce brackish water which maintains the lake's ecological balance (Guerrero, 1996). According to fisherfolk groups, however, various pests, specifically water hyacinths and predator fish species such as the snake turtle, knife fish, and janitor fish, have been thriving ever since the construction of the Napindan Hydraulic Control structure in Taguig City. Built as a flood control measure for Metro Manila, the Napindan structure is closed during the rainy season to prevent the overflow of rainwater into densely populated Metro Manila. It is supposed to be opened during the dry season, however, to allow saltwater to flow into Laguna Lake due to its fishing benefits. Yet during the FGDs, fisherfolk expressed their suspicion that the Napindan structure is no longer being opened during the dry season as water from the lake is also being used for the domestic water supply and for watering golf courses in southern Metro Manila.

Lake water eutrophication that causes the fast growth and spread of water hyacinths in Laguna Lake reduces even further the miniscule fishing income of households in the lakeshore communities. Water hyacinths obstruct the movement of fishing boats and make fishing activities difficult-and, on many occasions, even prevent these completely-for several days and weeks. Water pollution and other activities (such as land conversion, land reclamation, and the construction of the Laguna Lake Highway) also disturb the lake's ecological balance, leading to the emergence of predators that reduce fish populations and lower daily fish catches. These factors contribute negatively to the worsening living conditions of poor fishing households and increase their economic vulnerability. Nearly half (49\%) of the respondents in Sampad claimed that their households have missed meals in the past 12 months. The proportion in Sampiruhan was lower, though still substantial, at $27 \%$ (Palanca-Tan, 2020). 


\section{CONCLUDING REMARKS}

This study assessed the benefits derived from fishing in Laguna Lake from the perspective of low-income fishing communities using primary data gathered through FGDs, KIIs, and a household survey as well as secondary data from LLDA. The findings and some policy implications are summarized below.

First, the survey reveals that fisher households in the lakeshore communities are engaged mostly in subsistence open fishing. Only a few relatively well-off residents are able to construct and operate fish cages while corporations and nonresident individuals own and operate fish pens. Open fishing contributes more to fish production value and employment than does aquaculture (fish cages and pens combined), even if aquaculture generates more resource rent per hectare of the lake. Due to the very small number of entities (corporations and individuals) engaged in aquaculture, the huge resource rents generated from the lake benefit only a few fish farm operators from outside the lakeshore communities.

The challenge, therefore, is to institute a system wherein huge resource rents from aquaculture can accrue to poor fishing households in the lakeshore communities. One way is to collect higher permit fees from fish farm owners and use the proceeds to provide assistance to open fisherfolk and small-scale fish farm operators (such as the fish cage operators in Sampad and fishpond operators in Sampiruhan). Another way is to promote and facilitate the creation and initial organization of cooperatives of poor fisherfolk for the operation of large-scale fish pens. In doing so, huge resource rents generated from aquaculture can accrue to fisherfolk members of such cooperatives.

Second, there is a need for policymakers to realize the optimum level of fishing output from the lake by addressing the issue of pollution. Aquaculture in Laguna Lake is dependent largely on natural food, and hence does not cause the pollution problems common in intensive feeds-dependent aquaculture environments. It is actually the fishing activities, including fish farm operations, that are negatively affected by the lake's poor water quality. Laguna Lake water is highly eutrophic (Delima \& Baldia, 2012) as a result of inadequately treated domestic wastewater flowing in from congested Metro Manila and surrounding cities in Rizal and Laguna. This is one more compelling reason for government to implement a decisive and comprehensive sewerage program. 
Poor lake water quality that impedes fish growth and causes the excessive proliferation of water hyacinths is also attributed to another factor-blockage of saltwater flow from Manila Bay. Fisherfolk suspect that saltwater is no longer being allowed to flow into the lake through the Napindan structure as water from the lake is being extracted for domestic water supply and watering golf courses. This is an issue of competing uses-does LLDA still consider fishing as the foremost function of Laguna Lake? If yes, then protection of the lake for fishing purposes needs to be prioritized. If other uses are turning out to be gaining precedence over fisheries, then government needs to be transparent about such and have plans for providing alternative sources of livelihood for the fishing households as well as for filling the fish supply gap that will result from the change in priority. It is also imperative that government examines carefully whether or not this change of priority is consistent with its poverty alleviation and income redistribution programs. Palanca-Tan (2018) notes the potentially significant contribution of aquaculture to poverty alleviation as it provides not only a major source of income to fishing communities around water bodies but also, and more broadly, a cheap source of protein for the growing population.

\section{REFERENCES}

ADB [Asian Development Bank]. 2005. An evaluation of small-scale freshwater rural aquaculture development for poverty reduction. Manila: Operations Evaluation Department, Asian Development Bank.

Alcantara, A. J., Sobremisana, M. J., Espaldon, M. V. O., Alaira, S. A., Sevilla, C. C., Valdez, C. A., Paraso, M. G. V., \& Dela Cruz, A. E. 2008. GIS-aided animal production impacts analysis on the environment in Laguna Province. Journal of Environmental Science and Management, 11(2): 42-57.

Baldia, S. F., Conaco, M. C. G., Nishijima, T., Imanishi, S., \& Harada, K.-I. 2003. Microcystin production during algal bloom occurrence in Laguna de Bay, the Philippines. Fisheries Science, 69(1): 110-116.

Barril, C. R., \& Tumlos, E. T. 2002. Water quality trends and trophic state assessment of Laguna de Bay, Philippines. Aquatic Ecosystem Health \& Management, 5(2): 115-126. 
Chavez, H. M., Casao, E. A., Villanueva, E. P., Paras, M. P., Guinto, M. C., \& Mosqueda, M. B. 2006. Heavy metal and microbial analysis of janitor fish (Pterygoplichthys spp.) in Laguna de Bay, Philippines. Journal of Environmental Science and Management, 9(2): 31-40.

City Government of Calamba Official Website. 2018. City profile. Available at https:// www.calambacity.gov.ph/index.php/ct-menu-item-3/city-profile.

Delima, P. C., \& Baldia, S. P. 2012. Limnological analysis of Laguna de Bay Lake at Binangonan freshwater station: Its implication to plankton diversity. IAMURE International Journal of Ecology and Conservation, 2(1).

DSWD [Department of Social Welfare and Development]. 2015. Unpublished report on DSWD activities in Rizal.

Gong, W., Sakurai, R., \& Kada, R. 2015. Understanding local fish consumption behavior in Laguna Lake watershed area, Philippines. African Journal of Food Science, 9(4): 176-181.

Guerrero, R. D. 1996. Human impacts on Laguna de Bay, Philippines and management strategies for their mitigation. GeoJournal, 40(1-2): 69-72.

Israel, D. C. 2008. Fishpen and fishcage culture in Laguna de Bay: Status, economic importance, and the relative severity of problems affecting its practice. Philippine Journal of Development, 35(1): 55-92.

Laguna de Bay Technical Working Group. 2016. Pilot ecosystem account for Laguna de Bay basin. Quezon City: WAVES; Laguna Lake Development Authority.

LLDA [Laguna Lake Development Authority]. 2018. Unpublished list of registered fish pens and cages in Laguna Lake.

Maruyama, S., \& Kato, H. 2017. Identification of waters incorporated in Laguna Lake, Republic of the Philippines, based on oxygen and hydrogen isotopic ratios. Water, 9: 328-342.

Nakajima, J., Nagaoka, H., \& Ohgaki, S. 1996. Water quality characteristics of Laguna de Bay, a shallow lake in the tropic area. Journal of Japan Society on Water Environment, 19(8): 664-667. 
Palanca-Tan, R. 2015. Knowledge, attitudes, and willingness to pay for sewerage and sanitation services: A contingent valuation survey in Metro Manila, Philippines. Journal of Environmental Science and Management, 18(2): 44-52.

Palanca-Tan, R. 2017. Health and water quality benefits of alternative sewerage systems in Metro Manila, Philippines. Environment and Urbanization, 29(2): 567-580.

Palanca-Tan, R. 2018. Aquaculture, poverty and environment in the Philippines. The Journal of Social, Political, and Economic Studies, 43(3/4): 294-315.

Palanca-Tan, R. 2020. Economic vulnerabilities of fishing-dependent households around Laguna Lake, Philippines. Philippine Journal of Science, 149(3-a): 815-829.

PSA [Philippine Statistics Authority]. 2016. 2015 census of population report no. 1-F Region IV-A-Calabarzon: Population by province, city, municipality, and barangay. Quezon City: Philippine Statistics Authority. Available at http://www. psa.gov.ph/sites/default/files/04_Region\%204A.pdf.

PSA. 2019. Fisheries statistics of the Philippines 2016-2018. Quezon City: Philippine Statistics Authority. Available at https://psa.gov.ph/sites/default/ files/Fisheries\%20Statistics\%20of\%20the\%20Philippines\%2C\%202016-2018.pdf.

Rosales, C. A. M., \& Rollon, A. P. 2011. Factors affecting the occurrence and growth of toxic Cyanobacteria microcystis Aeruginosa in Laguna de Bay, Philippines. Journal of Environmental Science and Engineering, 5: 1109-1116.

Saguin, K. 2014. Biographies of fish for the city: Urban metabolism of Laguna Lake aquaculture. Geoforum, 54: 28-38.

Tamayo-Zafaralla, M., Santos, R. A. V., Orozco, R. P., \& Elegado, G. C. P. 2002. The ecological status of Lake Laguna de Bay, Philippines. Aquatic Ecosystem Health \& Management, 5(2): 127-138.

Tirado, R., Bedoya, D., \& Novotny, V. 2008. Agrochemical use in the Philippines and its consequences to the environment. Quezon City: Greenpeace Southeast Asia. 
Varca, L. M. 2012. Pesticide residues in surface waters of Pagsanjan-Lumban catchment of Laguna de Bay, Philippines. Agricultural Water Management, 106: 35-41.

Vicente-Beckett, V. A., Pascual, C. B., Kwan, C. S., \& Beckett, R. 1991. Levels and distribution of trace metals in sediments of Laguna Lake (Philippines) and its tributary rivers. International Journal of Environmental Analytical Chemistry, 45(2): 101-116.

Rosalina Palanca-Tan is a Professor of the Department of Economics, Ateneo de Manila University and obtained her PhD in Economics from Sophia University in Tokyo, Japan. She was a post-doctoral fellow at the Environmental Economics Unit of Gothenburg University (Sweden) as well as a visiting research fellow at the Institute of Environmental Studies of Tokyo University (Japan), the Institute of Comparative Culture of Kobe University (Japan), and the University of Amsterdam (Netherlands). Her research interests and publications are in the areas of environmental and natural resource economics, behavioral economics, health economics, and Philippines-JapanASEAN economic relations. 